ERR A T UM

F. Chen $\cdot$ W. Siebel $\cdot$ M. Satir

\title{
Geochemical and isotopic composition and inherited zircon ages as evidence for lower crustal origin of two Variscan S-type granites in the NW Bohemian massif
}

Published online: 26 June 2003

(C) Springer-Verlag 2003

\section{Int J Earth Sci (Geol Rundsch) (2003) 92:173-184}

Due to an unfortunate error, the name of the first author was published twice. The correct names of authors are printed above.

The online version of the original article can be found at http:// dx.doi.org/10.1007/s00531-003-0310-6

F. Chen $(\bowtie) \cdot$ W. Siebel · M. Satir Institut für Geowissenschaften,

Universität Tübingen,

Wilhelmstraße 56, 72074 Tübingen, Germany

e-mail: fukun.chen@uni-tuebingen.de

Fax: +86-10-62010846

Present address:

F. Chen, Institute of Geology and Geophysics, Chinese Academy of Sciences,

P.O. Box 9825, 100029 Beijing, P.R. China

E-mail: fukun-chen@mail.igcas.cn 